Journal of Antimicrobial Chemotherapy (1991) 28, Suppl. C, 9-14

\title{
In-vitro activity of temafloxacin for Gram-positive pathogens
}

\author{
Jacques Bille' and Michel P. Glauser \\ ${ }^{\circ}$ Clinical Bacteriology Laboratory; ${ }^{\circ}$ Division of Infectious Diseases, Department of \\ Internal Medicine, Centre Hospitalier Universitaire Vaudois, Lausanne, Switzerland
}

\begin{abstract}
The antimicrobial activity of temafloxacin against aerobic Gram-positive cocci was compared to that of ciprofloxacin, ofloxacin, fleroxacin and pefloxacin using the broth microdilution technique. Temafloxacin was more active than the other four fluoroquinolones, particularly for viridans streptococci and Streptococcus pneumoniae. The $\mathrm{MIC}_{\infty_{0}}$ of temafloxacin was at least four-fold lower than that of ciprofloxacin and ofloxacin for viridans streptococci and penicillin-susceptible pneumococci. The $\mathrm{MIC}_{50} \mathrm{~s}$ and $\mathrm{MIC}_{90} \mathrm{~s}$ of temafloxacin were equal to or lower than those of the other fluoroquinolones for methicillin-susceptible Staphylococcus aureus (MSSA), methicillin-resistant S. aureus (MRSA), and methicillin-susceptible and methicillin-resistant coagulase-negative staphylococci. Temafloxacin was more active against all the other Gram-positive aerobes (except Enterococcus faecalis) tested than the other fluoroquinolones.
\end{abstract}

\section{Introduction}

Streptococcus pneumoniae and other Gram-positive cocci remain important human pathogens. While penicillin has been active against these organisms for many years, its wide and often indiscriminate use has led to penicillin resistance, with estimated prevalence rates of between $10 \%$ and $40 \%$ in parts of Europe (Baquero, Martinez-Beltran \& Loza, 1991). Thus, the search for new therapeutic agents with activity against penicillin-resistant Gram-positive cocci is important. One such group of antimicrobial agents is the fluoroquinolones.

The antimicrobial activity of temafloxacin is distinguished from that of other fluoroquinolones by its extended activity against Gram-positive aerobes (particularly Gram-positive cocci), intracellular organisms (Chlamydia, Mycoplasma, and Legionella spp.) and anaerobes. This increased activity is especially relevant to $S$. pneumoniae. The $\mathrm{MIC}_{50}$ and $\mathrm{MIC}_{90}$ of temafloxacin for $S$. pneumoniae were reported to be $0.25 \mathrm{mg} / \mathrm{L}$ and $\leqslant 0.5 \mathrm{mg} / \mathrm{L}$, respectively (Loza et al., 1990; Digranes et al., 1989). The $\mathrm{MIC}_{90} \mathrm{~s}$ of ofloxacin and ciprofloxacin for the same isolates were approximately two-fold greater.

In the present study the in-vitro activity of temafloxacin was determined for a range of recent Gram-positive clinical isolates and compared with that of four other fluoroquinolones.

\section{Materials and methods}

A total of 190 Gram-positive pathogens recently isolated from patients at the University Hospital, Lausanne, were initially frozen at $-80^{\circ} \mathrm{C}$ in lysed horse blood. 
Table. In-vitro activity of temafloxacin, ciprofloxacin, ofloxacin, fleroxacin and pefloxacin for Gram-positive aerobic clinical isolates

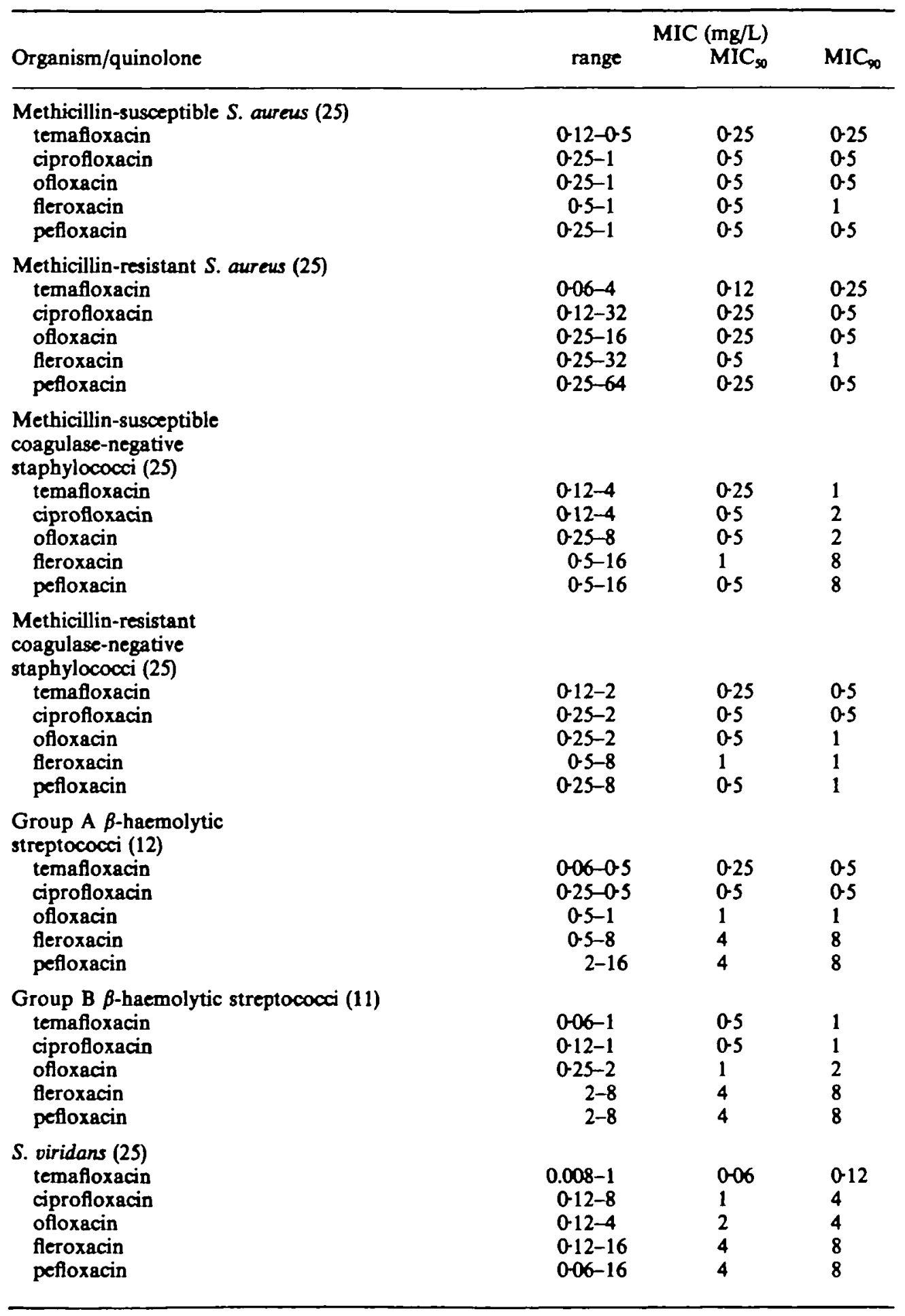


Table-continued

\begin{tabular}{|c|c|c|c|}
\hline Organism/quinolone & range & $\begin{array}{l}(\mathrm{mg} / \mathrm{L}) \\
\mathrm{MIC}_{30}\end{array}$ & $\mathrm{MIC}_{90}$ \\
\hline $\begin{array}{l}\text { Enterococcus faecalis } \\
\text { temafloxacin } \\
\text { ciprofloxacin } \\
\text { ofloxacin } \\
\text { fleroxacin }\end{array}$ & $\begin{array}{r}0-5-4 \\
0-25-4 \\
1-4 \\
2-8\end{array}$ & $\begin{array}{l}1 \\
1 \\
4 \\
8\end{array}$ & $\begin{array}{l}4 \\
2 \\
4 \\
8\end{array}$ \\
\hline $\begin{array}{l}\text { Penicillin-susceptible } \\
\text { temafloxacin } \\
\text { ciprofloxacin } \\
\text { ofloxacin } \\
\text { fleroxacin } \\
\text { pefloxacin }\end{array}$ & $\begin{array}{c}<0-004-0-12 \\
0-25-4 \\
0-5-2 \\
2-4 \\
1-16\end{array}$ & $\begin{array}{l}0-12 \\
0.5 \\
1 \\
4 \\
2\end{array}$ & $\begin{array}{l}0-12 \\
4 \\
2 \\
4 \\
16\end{array}$ \\
\hline $\begin{array}{l}\text { Penicillin-resistant } S \\
\text { temafloxacin } \\
\text { ciprofloxacin } \\
\text { ofloxacin } \\
\text { fleroxacin } \\
\text { pefloxacin }\end{array}$ & $\begin{array}{c}<0-004-0-12 \\
0-12-2 \\
1-2 \\
2-4 \\
2-4\end{array}$ & $\begin{array}{l}0-06 \\
0.5 \\
1 \\
4 \\
4\end{array}$ & $\begin{array}{l}0-12 \\
2 \\
2 \\
8 \\
4\end{array}$ \\
\hline
\end{tabular}

Penicillin MIC: range 0-12-2-0; MIC $10 ; \mathrm{MIC}_{\infty} 2-0$.

Susceptibility of the isolates to temafloxacin, ciprofloxacin, ofloxacin, fleroxacin, and pefloxacin was determined by the broth microdilution technique in accordance with NCCLS recommendations (NCCLS, 1982). The medium was a unique batch of Mueller-Hinton broth with cation supplementation $\left(50 \mathrm{mg} / \mathrm{L} \mathrm{Ca}^{++}, 25 \mathrm{mg} / \mathrm{L} \mathrm{Mg}^{++}\right)$. The inoculum was $10^{5} \mathrm{cfu} / \mathrm{mL}\left(10^{4} \mathrm{cfu} /\right.$ well of microtitre plate).

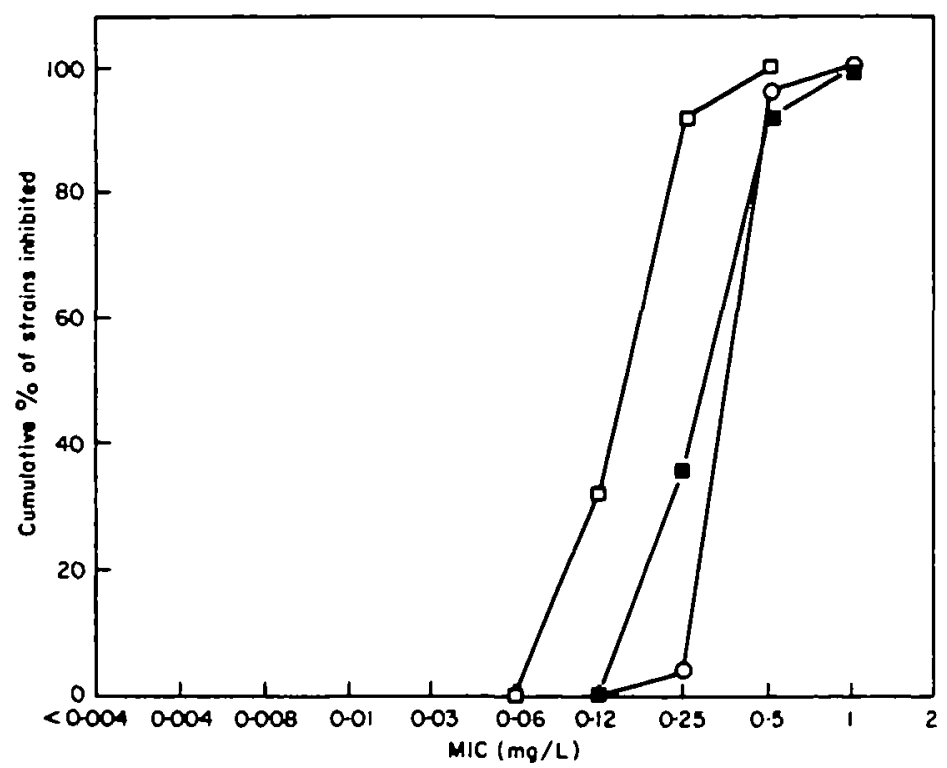

Figure 1. Distribution of MIC values for methicillin-susceptible $S$. aureus. $\square$, Temafloxacin; $\square$, ciprofloxacin; O, ofloxacin. 


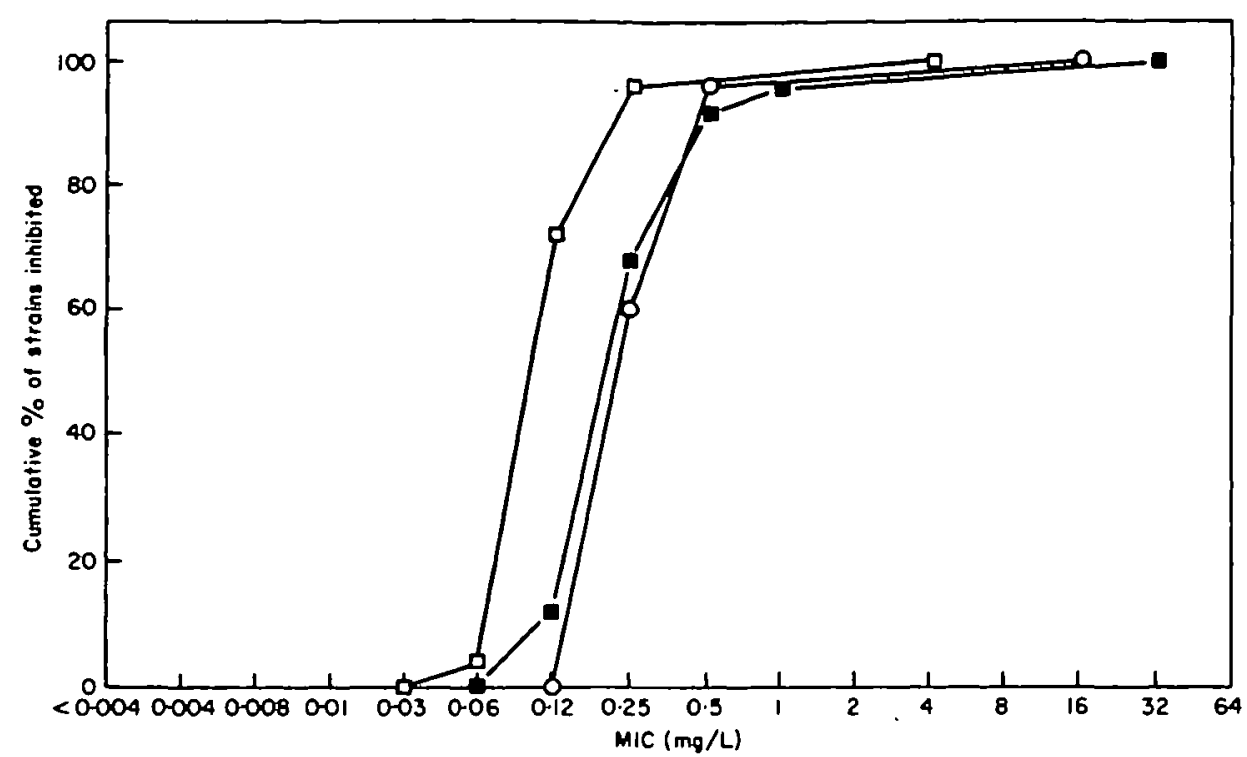

Figure 2. Distribution of MIC values for methicillin-resistant $S$, aurews. $\square$, Temafloxacin; $\square$, ciprofloxacin; $O$, ofloxacin.

\section{Results}

Temafloxacin was more active against Gram-positive bacteria than were ciprofloxacin and the three other fluoroquinolones (Table). Temafloxacin was particularly active for viridans streptococci and $S$. pneumoniae. The $\mathrm{MIC}_{\infty}$ of temafloxacin for viridans streptococci was $0.12 \mathrm{mg} / \mathrm{L}$, compared to $4 \mathrm{mg} / \mathrm{L}$ of ciprofloxacin and ofloxacin. The

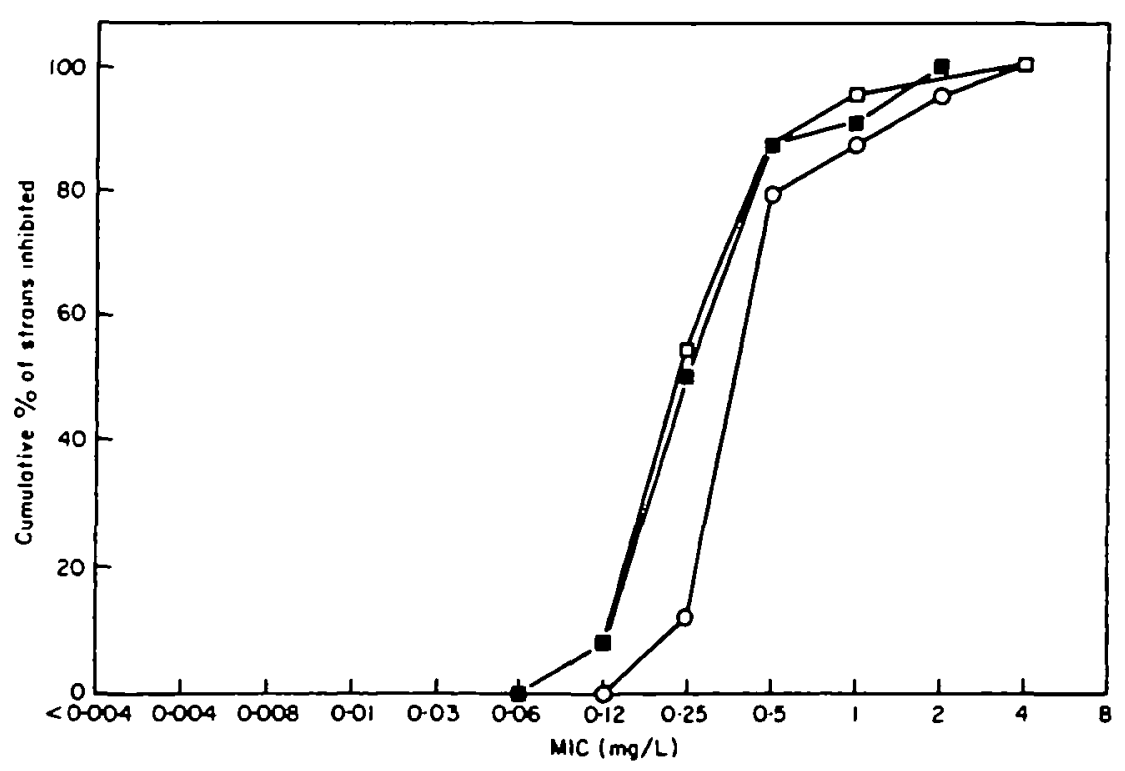

Figure 3. Distribution of MIC values for methicillin-sueceptible coagulase-negative staphylococci. $\square$. Temafloxacin; $\square$, ciprofloxacin; $O$, ofloxacin. 


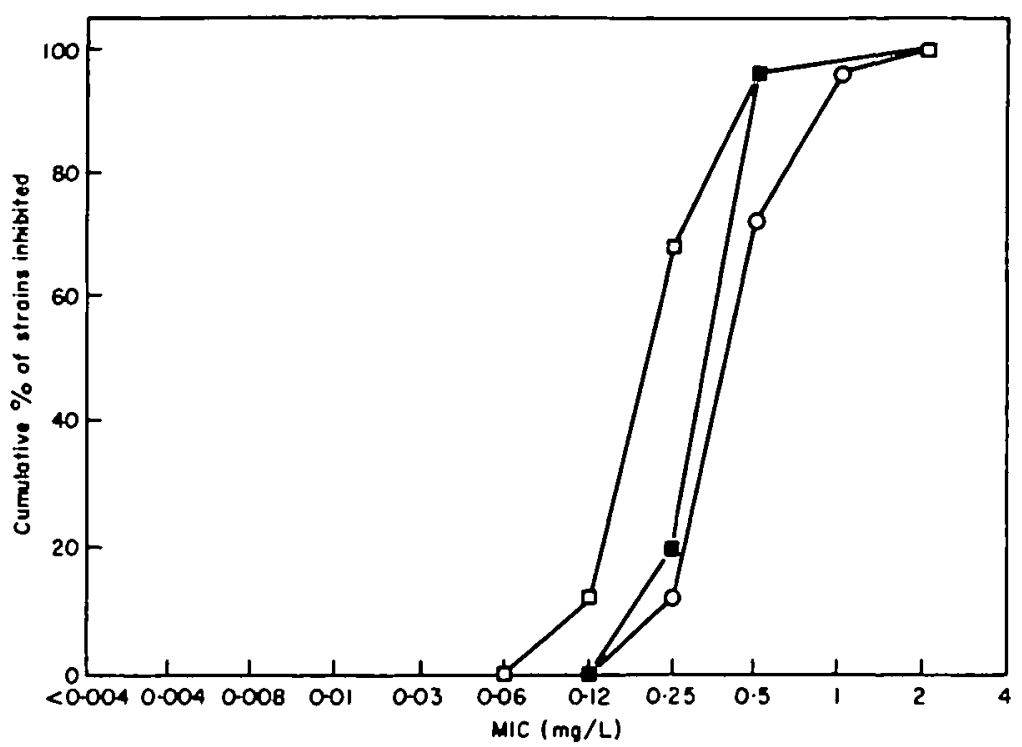

Figure 4. Distribution of MIC values for methicillin-resistant coagulase-negative staphylococci. $\square$. Temafloxacin; $\square$, ciprofloxacin; $O$, ofloxacin.

$\mathrm{MIC}_{90}$ of temafloxacin for penicillin-susceptible pneumococci was $0.12 \mathrm{mg} / \mathrm{L}$, compared to $4 \mathrm{mg} / \mathrm{L}$ of ciprofloxacin and $2 \mathrm{mg} / \mathrm{L}$ of ofloxacin. A temafioxacin concentration of $0.12 \mathrm{mg} / \mathrm{L}$ inhibited $90 \%$ of penicillin-resistant pneumococi, compared to $2 \mathrm{mg} / \mathrm{L}$ of ciprofloxacin and ofloxacin.

The distribution of MICs of temafloxacin, ciprofloxacin and ofloxacin for staphylococci are shown in Figures 1 to 4 . The $\mathrm{MIC}_{50} \mathrm{~s}$ and $\mathrm{MIC}_{90} \mathrm{~s}$ of temafloxacin were less than or equal to those of ciprofloxacin and ofloxacin for methicillin-susceptible $S$. aureus (MSSA), methicillin-resistant $S$. aureus (MRSA), methicillin-susceptible coagulase-negative staphylococci, and methicillin-resistant coagulase-negative staphylococci.

\section{Discussion}

Temafloxacin has similar activity to other fluoroquinolones against Gram-negative aerobic organisms, but its activity is distinguished from that of other fluoroquinolones by its enhanced potency against Gram-positive aerobes. The activity of temafloxacin against Gram-positive cocci, particularly $S$. pneumoniae and $S$. aureus, exceeds that of other quinolones (Digranes et al., 1989; Nye et al., 1989; Mazzulli et al., 1990). Temafloxacin has been shown to possess better in-vitro bacteristatic and bactericidal activity against clinically significant staphylococcal isolates than ciprofloxacin and ofloxacin (Fuchs \& Barry, 1991). The improved activity of temafloxacin compared to earlier fluoroquinolones against Gram-positive bacteria described by other workers has been confirmed in this institution, with the activity of temafloxacin against staphylococci at least one tube-dilution lower than the other quinolones tested, and against $S$. pneumoniae at least four-fold more active regardless of penicillin susceptibility. 


\section{References}

Baquero, F., Martinez-Beltrán, J. \& Loza, E. (1991). A review of antibiotic resistance patterns of Streptococcus preumoniae in Europe. Journal of Antimicrobial Chemotherapy 28, Suppl. C, 31-8.

Digranes, A., Hardardottir, H., Liland, K. \& Lindgren, B. (1989). Temafloxacin: in-vitro comparison with ciprofloxacin, ofloxacin, ceftazidime, and tobramycin. In Proceedings of the Sixteenth International Congress of Chemotherapy, Jerusalem, 1989.

Fuchs, P. C. \& Barry, A. L. (1991). Temafloxacin in-vitro antistaphylococcal activity compared to that of other fluoroquinolones. Proceedings of the Seventeenth Congress of Chemotherapy. Berlin, 1991. Abstract 2030.

Loza, E., Martínez-Beltrán, J., Liñares, J., Cercenado, E., Dámaso, D., Bouza, E. et al. (1990). Temafloxacin (II): multicentric study of the intrinsic activity on Gram-positive organisms. Third International Symposium on New Quinolones, Vancouver, 1990. Abstract 53.

Mazzulli, T., Simor, A. E., Jaeger, R., Fuller, S. \& Low, D. E. (1990). Comparative in vitro activities of several new fluoroquinolones and $\beta$-lactam antimicrobial agents against community isolates of Streptococcus pneumoniae. Antimicrobial Agents and Chemotherapy 34, 467-9.

National Committee for Clinical Laboratory Standards. (1982). Standard Methods for Dilution Antimicrobial Susceptibility Tests for Bacteria which Grow Aerobically; Tentative Standard: M7-T. NCCLS, Villanova, PA.

Nye, K., Shi, Y. G., Andrews, J. M., Ashby, J. P. \& Wise, R. (1989). The in-vitro activity, pharmacokinetics and tissue penetration of temafloxacin. Journal of Antimicrobial Chemotherapy 24, 415-24. 